\title{
IMPROVEMENT OF HYDRAULIC PRESS FOR VEGETABLE OIL EXPRESSION IN RURAL AREAS
}

\author{
Oscar Kibazohi and Leonard Damson \\ Department of Chemical and Mining Engineering, \\ University of Dar es Salaam, P. O. Box 35131 Dar es Salaam - Tanzania, \\ Email: kibazohi@udsm.ac.tz
}

\begin{abstract}
Cultivation of oil producing crops especially Jatropha and croton as source of vegetable oil for biodiesel production is being encouraged in rural areas. To recover oil from seed, manual press is the feasible method in rural areas where there is no electricity. Research was conducted to improve hydraulic oil press machine for rural application. Factors affecting oil recovery were found to be: moisture content of seeds, operating pressure, seed oil content, and the amount of seeds pressed per batch. Percentage oil recovery was improved by reducing diameter of press cylinder, hence increasing expression pressure, and either reducing amount of seed processed per batch or placing disk within the seeds to improve oil flow. The maximum vegetable oil recovered from Jatropha seeds at a pressure of $20.8 \mathrm{MPa}$ after improvement was $57.5 \%$ of the total oil in seeds. There was no significant difference in terms of oil recovery between pressing whole seeds or milled seeds. Suggested further improvement includes: higher pressure than $20.8 \mathrm{MPa}$, reduced radial distance travelled by oil and replacement of hydraulic jack with a self retracting double acting hydraulic power cylinder to reduce batch cycle.
\end{abstract}

Keywords: Vegetable oil, Oil recovery, Oil press, Jatropha

\section{INTRODUCTION}

Introduction of converting vegetable oils to bio-diesel technology in Tanzania is expected to bring a significant change in agriculture sector. Recently, emphasis has been put into growing Jatropha plants, a potential source of raw material in production of bio-diesel. There are many advantages of bio-diesel over petroleum diesel; biodiesel is renewable and environmentally friendly. Farmers are likely to benefit from cultivating oil producing plants such as Jatropha and croton if they can express oil from seeds instead of selling whole seeds. In addition, they may use extracted oil for lighting and cooking (de Jongh, 2010).

Methods of recovering oil from seeds include oil expression using expellers, manual presses machines such as ram and hydraulic press and solvent extraction. Solvent extraction is the most efficient method that can recover most of the oil contained in the seeds leaving behind a cake with only $1 \%(\mathrm{w} / \mathrm{w})$ oil (Considine and Considine, 1982; Kibazohi, 2006 and de Jongh, 2010). However, this method is expensive and only feasible for large scale production, and requires skilled personnel. Oil expression by power driven expellers is next to solvent extraction method in term of efficiency leaving behind a solid cake with 8 to $10 \%(\mathrm{w} / \mathrm{w})$ oil (Considine and Considine, 1982; Kibazohi, 2006). However, oil expellers are driven by electric power or internal combustion engines both of which are either not available in rural areas or expensive for small scale farmers.

The third and least efficient method is oil expression by manual presses which is the cheapest method for recovering oil from seeds, nuts, and kernels when compared to others and does not require skilled 
labor

1992; http://www.appropedia.org; de manual presses an alternative achievable choice for local small scale farmers, most of which are unskilled and conduct agriculture activities in remote areas where electric power is not available. Manual presses come in different forms e.g. ram press, curb press, scissor press and hydraulic press (Figure 1). Most of manual press are inefficient and have small seed processing capacity and they leave larger quantity (up to $50 \%$ ) of total oil in press. The remaining oil in press cake is not further extracted by solvent therefore larger quantity of oil is wasted when the cake is disposed off.
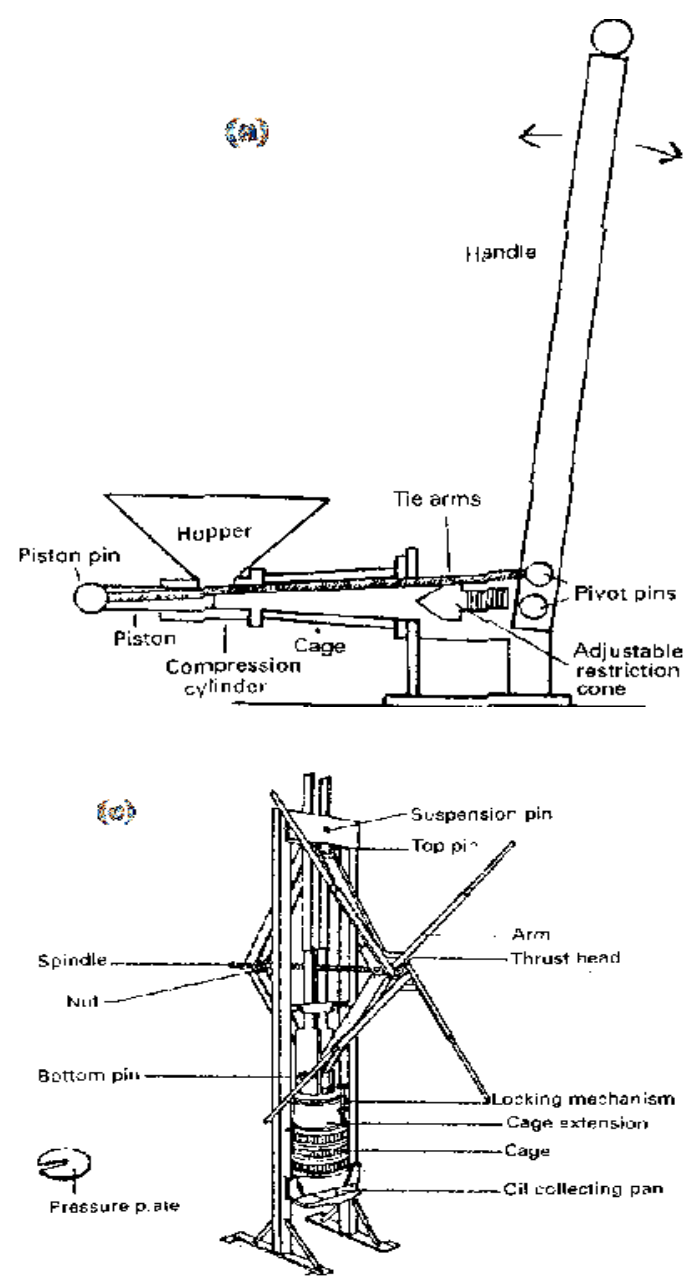
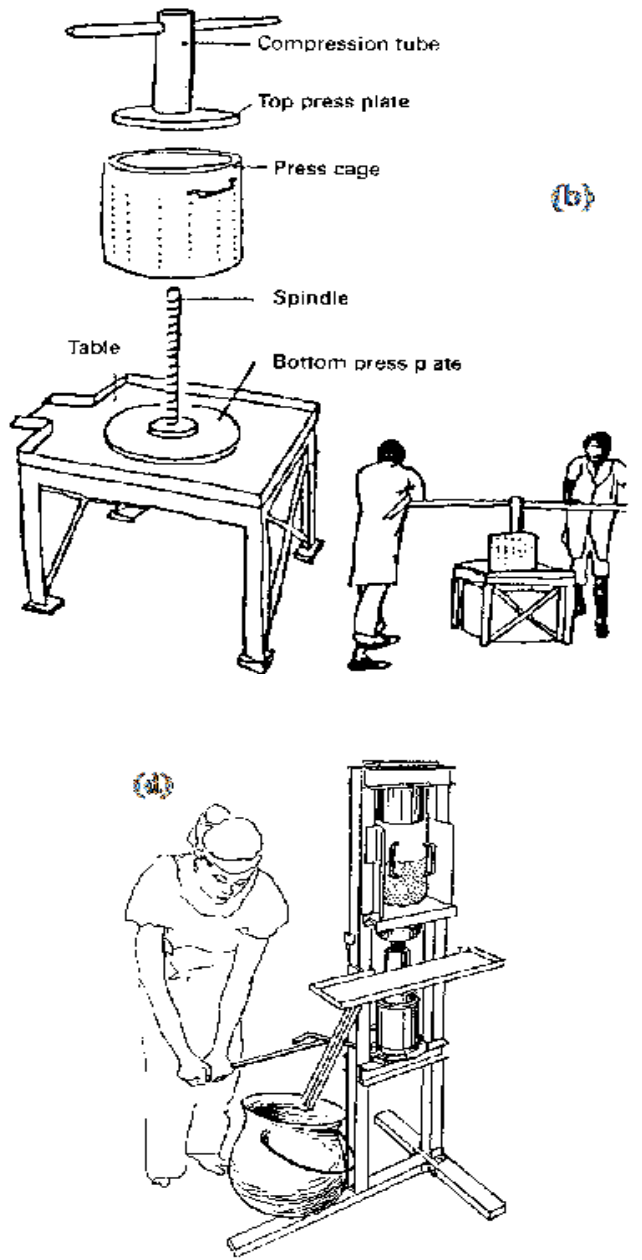

Source:http://www.appropedia.org/Small_Scale_Vegetable_Oil_Extraction

Figure 1: Various manual oil presses: (a) ram press, (b) curb press, (c) scissor press, and (d) hydraulic press 


\section{METHODS AND MATERIALS}

Hydraulic oil press machine was constructed from15 tons hydraulic jack, steel cylinder of $15.6 \mathrm{~cm}$ diameter, piston plate, four steel rods of $2.5 \mathrm{~cm}$ diameter with $60 \mathrm{~cm}$ length, two steel plates of $2.5 \times 17.5 \times 29.4 \mathrm{~cm}$ and M16 bolts as shown in Figure2. The jack capacity was verified by operating its manual hydraulic pump to maximum pressure, (until pumping was no longer possible), between jaws of a laboratory hydraulic press equipped with a force gauge; the jack proved to have 15 ton capacity. With exception of the jack all components were machined to specifications at the Department of Chemical and Mining Engineering, University of Dar es Salaam. African Monsoon Multidisciplinary Analysis (AMMA) Company limited provided Jatropha seeds; groundnuts seeds were purchased from Mwenge local market in Kinondoni, Dar-es-Salaam. The normal hexane solvent $(99 \% \mathrm{w} / \mathrm{w})$ for oil extraction was purchased from Z.K. \& Company in Dar-es-Salaam, Tanzania. Other pieces of equipments such analytical balances, beakers, and soxhlet extractor were available at Department of Chemical and Mining Engineering.

Figure2 shows various parts of experimental hydraulic oil press fabricated according to Snyder and Casten (1985). Figure 2(a) is the press in vertical position; letters A, B, C, D and E show steel plate, hydraulic jack, piston, cylinder, and steel rod, respectively. Fig. 2(b) and (c) show the press in a horizontal orientation.

Jatropha seeds were measured using the scale balance and loaded in cylinder of the press machine. Using a jack, compression pressure was gradually increased until maximum pressure was attained when jack pump lever was not able to move further. The machine was left in that state while oil continued to ooze out. The pump lever was operated periodically to increase pressure whenever oil expression decreased until no more drops of oil drained out of compressed seeds. Weight of pressed oil was then measured using analytical balance. The cake from the machine was removed and another amount of fresh seeds loaded. Oil recovery attained for all experiments was recorded. The hydraulic jack pump did not function in what was supposed to be a convenient upside-down position. Therefore the press was placed in a horizontal position Figure 2(b) and 2(c).

To determine the variation of oil recovery with pressure a fixed amount of seeds was pressed in different cylinders of diameters $15.6 \mathrm{~cm}, 12.3 \mathrm{~cm}$ and of $9.5 \mathrm{~cm}$. Effect of grinding seeds (size reduction) on oil recovery was determined by using a hydraulic oil press machine with the 9.5 $\mathrm{cm}$ diameter cylinder. The experiment was performed by pressing whole Jatropha seeds and repeated with milled Jatropha seeds.

Rate of oil recovery was measured using a measuring cylinder and stopwatch. Volume of oil draining into the measuring cylinder was recorded every 2 minutes during oil expression.

Moisture content of seeds was determined by measuring the desired amount of seeds using analytical balance. The measured seeds were placed inside an oven at a temperature of $102^{\circ} \mathrm{C}$ until there was no further change in weight of seeds. Then the moisture content was calculated as difference between initial weight and final weights. 


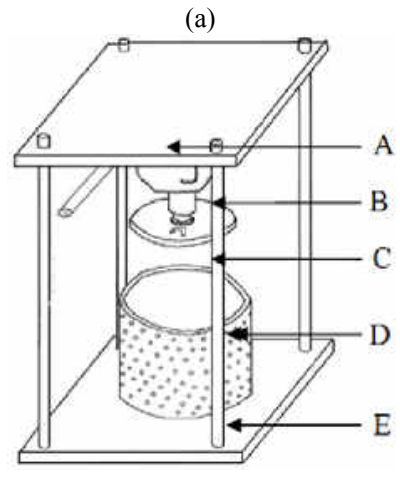

(b)

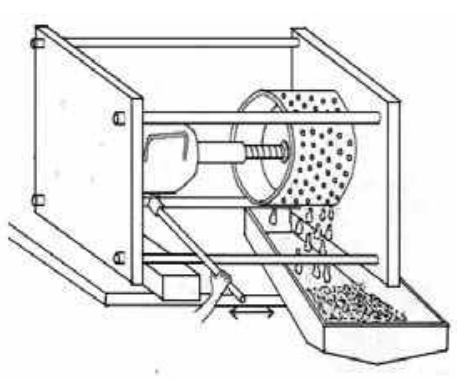

(c)

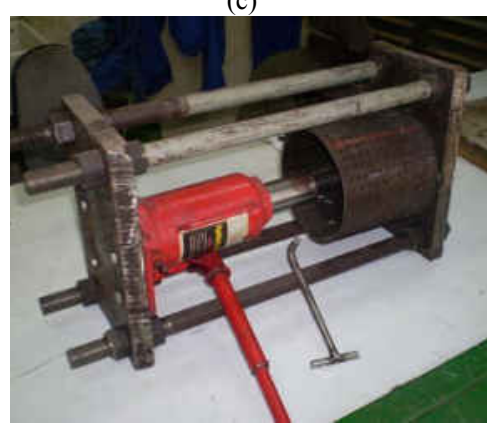

Figure 2: Experimental hydraulic oil press machine

Oil content of seeds was determined using a soxhlet extractor. The seeds were milled into fine particles using a disk-grinding machine. Approximately 27 grams of ground seed sample was weighed using analytical balance, introduced into $150 \mathrm{ml}$ thimble, and covered with cotton wool. The thimble was placed into the thimble holder and a $250 \mathrm{ml}$ round bottom flask containing $200 \mathrm{ml}$ of hexane solvent. The soxhlet flask was placed onto the heating element and electricity was turned on so as to evaporate and circulate the solvent through the sample, at the same time cooling water tape was turned on to condense the solvent vapor. The extraction process was conducted for 4 hours and duplicate runs were performed for the same sample. After extraction the round bottom flask containing a mixture of hexane and oil was detached from the thimble holder and connected to a distillation unit for separation of solvent from oil. The flask was partially immersed in a water bath at $70^{\circ} \mathrm{C}$. The distillation unit had a vacuum unit system set at 250 mbar absolute to assist the evaporation of hexane. Hexane vapor was cooled by refrigerated water entering the condenser at $10^{\circ} \mathrm{C}$. After separation the extracted oil remaining in the round bottom flask was placed into an oven at $105^{\circ} \mathrm{C}$ for 1 hour to remove any remaining solvent and water. The round bottom flask containing the oil was cooled to room temperature and weighed to obtain the weight of the extracted oil. The oil content of seeds was then calculated using equation (1).

\section{RESULTS AND DISCUSSION}

\section{Variation of oil recovery with amount of seeds pressed}

Percentage of oil recovery from Jatropha seeds varied with amount of seed loading (Figure 3). Results obtained using a 15.6 $\mathrm{cm}$ diameter cylinder showed that when 
the hydraulic oil press cylinder was fully loaded (16 cm deep), oil recovery attained was $30 \%$ (based on total seed oil). When the cylinder was half $(8 \mathrm{~cm}$ depth) and quarter (4 cm depth) loaded oil recovery increased to $35 \%$ and $39.5 \%$, respectively (Figure 3). This observation suggests that oil draining is resisted by the cake and smaller seed loading provides shorter distance travelled by the oil, hence slight improvement in oil yield. Based on above assumption, a steel disk of $5 \mathrm{~mm}$ thickness and same diameter as piston was positioned between the seeds during loading to improve oil flow. Oil recovery increased to $41 \%, 42 \%$ and $45 \%$ for full, half and quarter filled cylinder, respectively (Figure 3). Bargale et al. (1999) report similar observation of higher oil yield from soybean for shallow samples than deep samples. Bargale et al. (1999) explain that oil globules in the deep samples although exited from the ruptured cell walls, were entrapped by solid particles as a result of longer distance to be travelled.

\section{Variation of oil recovery with diameter of cylinder}

The results in Figure 4 shows that, hydraulic press design described by Snyder and Casten (1985) has low oil expression efficiency; changing the diameter of the hydraulic oil press cylinder from $15.6 \mathrm{~cm}$ to $12.3 \mathrm{~cm}$ and 9.5 $\mathrm{cm}$ increased Jatropha oil recovery for filled cylinder without partitioning plate to $39.9 \%, 50 \%$ and $57.6 \%$ of total seed oil, respectively. This improvement was a result of increase in pressure from 7.7 $\mathrm{MPa}$ to $12.4 \mathrm{MPa}$ and $20.8 \mathrm{MPa}$ for 15.6 $\mathrm{cm}, 12.3$ and $9.5 \mathrm{~cm}$ cylinder diameters, respectively.

\section{Effect of size reduction on oil recovery}

The oil recovery for grounded Jatropha seeds using a $9.5 \mathrm{~cm}$ cylinder was $55.47 \%$. This value is close to previous result of $57.6 \%$ for whole Jatropha seeds pressed in the same cylinder indicating that, there is no advantage of grinding seeds on the oil recovery.

\section{Rate of oil expression}

The flow rate of oil during expression is moisture content dependent. It was observed that for dried seeds of moisture content ranging between $6.5 \%$ and $7.5 \%$ (wet basis) the flow rate increased sharply during the first 10 minutes then fell sharply between 10th and 20th minutes as shown in Fig. 5(a) despite of increasing pressure. After twenty minutes oil flow decreased to almost zero and oil flow was achieved by periodically operating the hydraulic pump to maintain high pressure. If seeds with high moisture content (11$13 \%$ ) were pressed, oozing of oil from the machine was delayed for 10 minutes as shown in Figure 5(b). Literature suggests oilseed moisture content below $8 \%$ before oil expression (de Jongh, 2010). Kabutey et al. (2011) reports that deformation energy of Jatropha seeds decreases with increasing content which suggest that at higher moisture content, Jatropha seeds are more elastic and cells wall do not rapture to release oil globules as early as brittle cell walls or seeds with less moisture. 


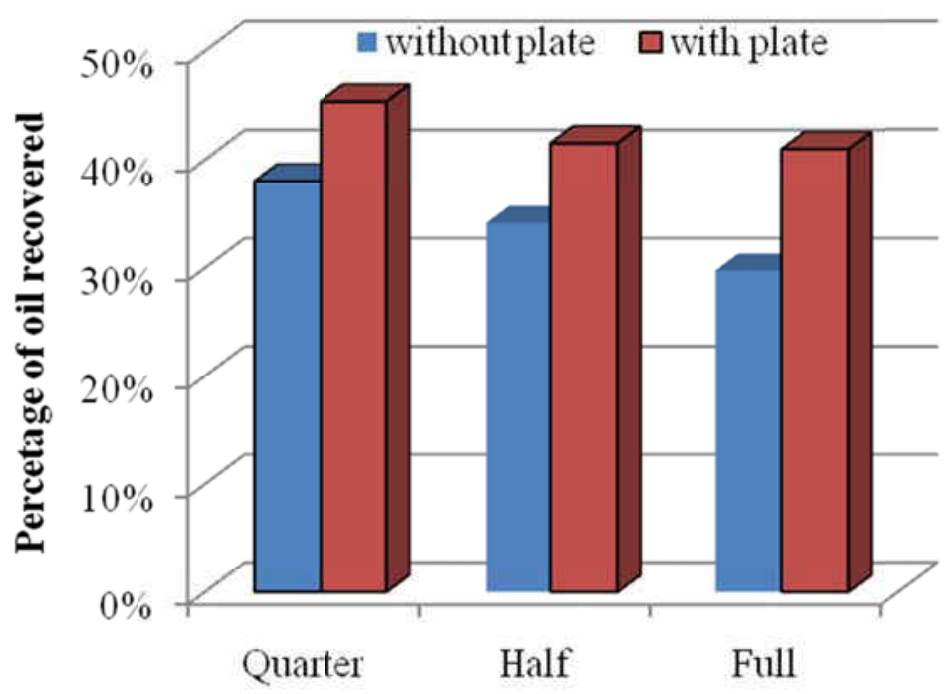

Amount of oilseeds

Figure 3: Variation of oil recovery with amount of pressed seeds in a $15.6 \mathrm{~cm}$ diameter cylinder without and with partitioning plate

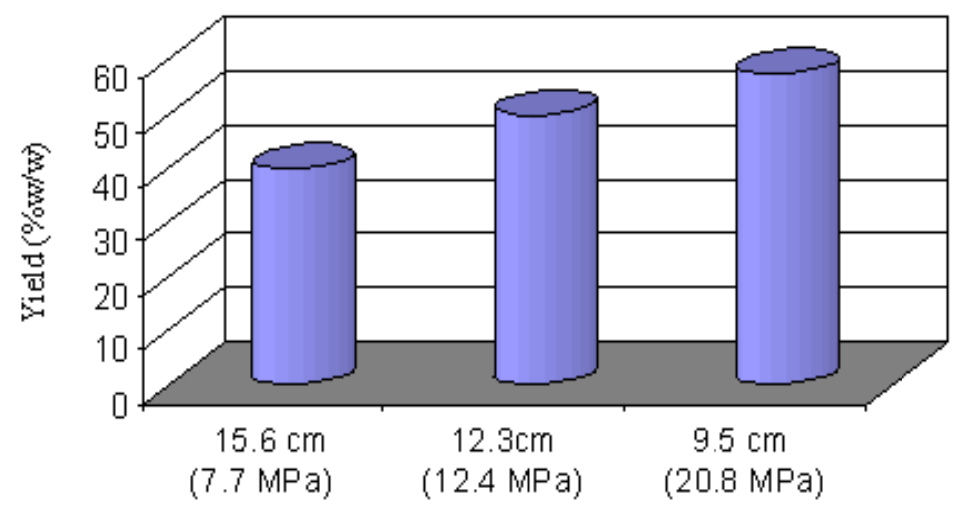

Figure 4: Variation of oil recovery with cylinder size

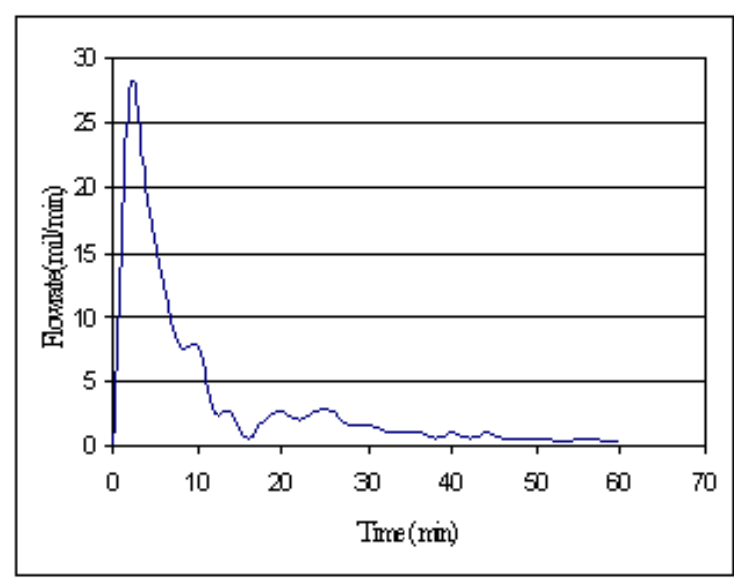

(a)

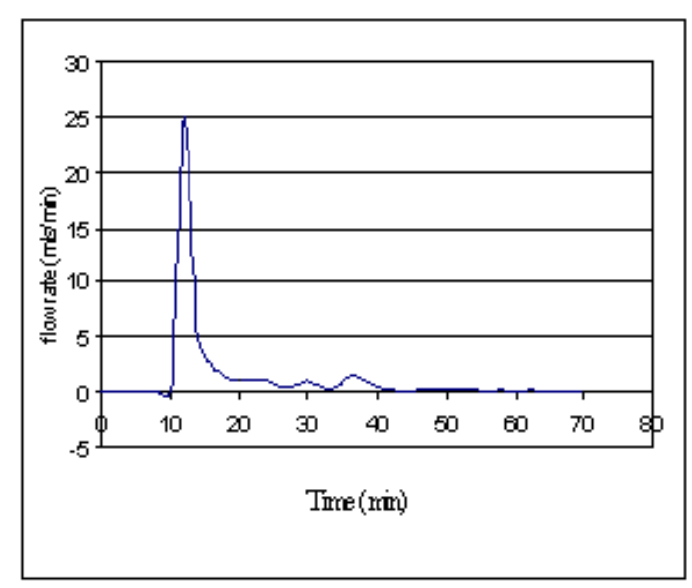

(b)

Figure 5: Oil flow rate versus time (Press loading of 1180 grams each) 
Economical time limit for draining oil from pressed seeds

To attain maximum oil recovery, seeds were supposed to be pressed at maximum pressure throughout the process. It took 50 minutes to obtain maximum oil recovery from seeds in all cases of different cylinder sizes (Figure 6). Therefore, it was recommended that if seeds are pressed in cylinder of diameter $15.6 \mathrm{~cm}$ oil recovery should take 40 minutes and then an operator has to remove cake for 10 minutes before processing a next batch. For the cylinder of $9.5 \mathrm{~cm}$ diameter, $55 \%$ of oil recovery was attained in 40 minutes beyond this time recovery increased by only $2 \%$ to $57 \%$. Therefore, it is recommended that collection of oil should last for 40 minutes after which an operator has to remove the seeds cake. To attain maximum recovery seeds are to be pressed in the cylinder of $9.5 \mathrm{~cm}$ diameter or small (at more than 20 $\mathrm{MPa})$.

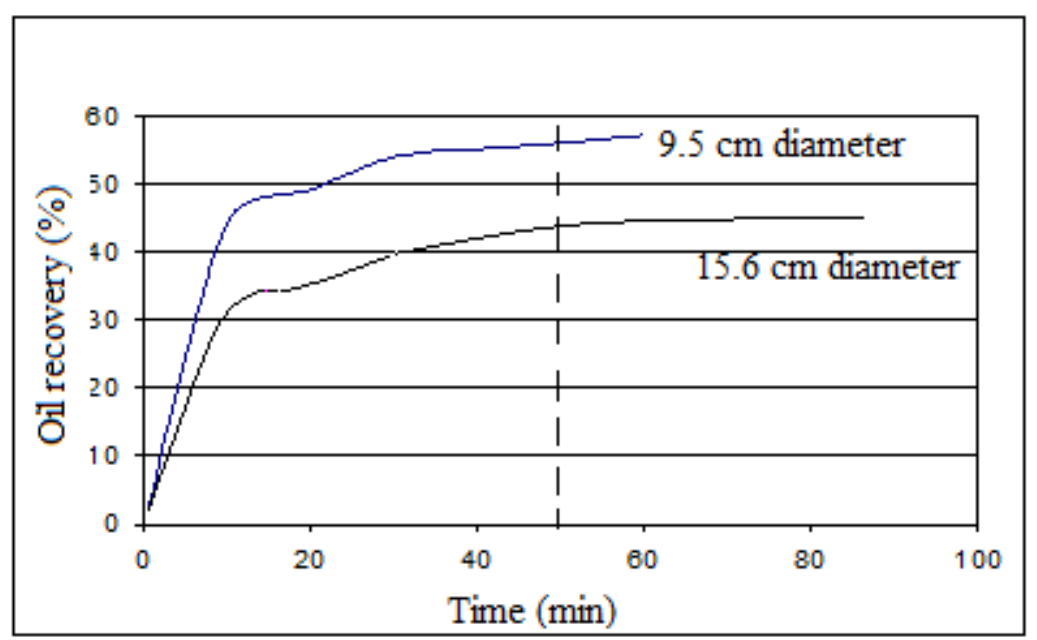

Figure 6: Variation of oil recovery with time

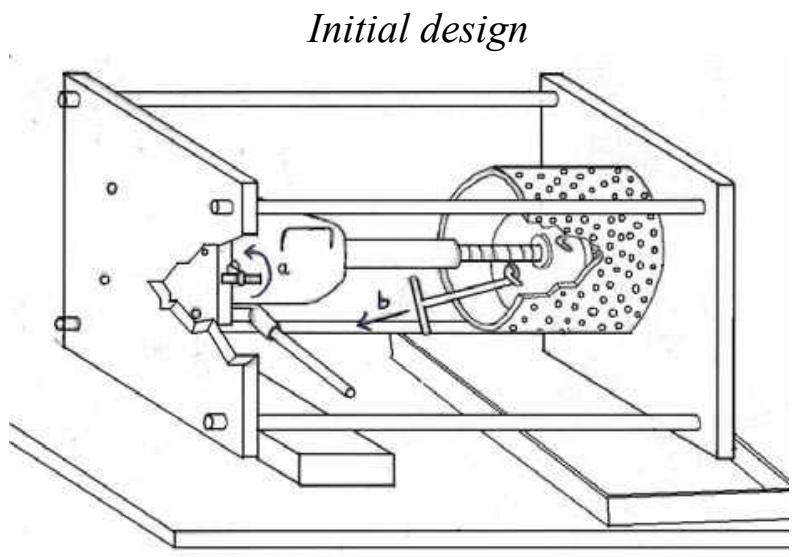

After modification

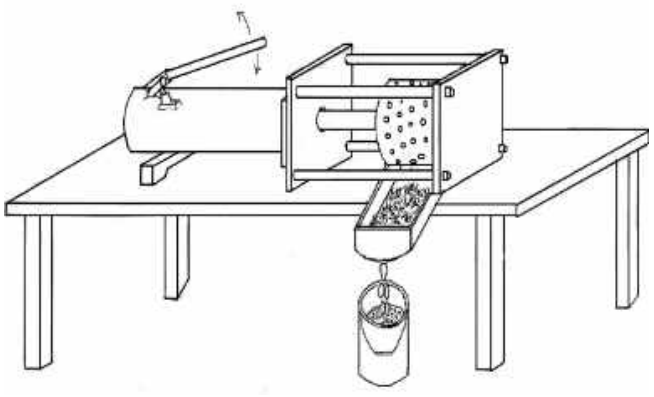

Figure 7: Modification of hydraulic oil press machine 


\section{Modification of the machine}

The hydraulic oil press machine shown in Figure 2(a) was fabricated based on design described by Snyder and Casten (1985) in which a 15 tons hydraulic jack and cylinder diameter of $15.6 \mathrm{~cm}$ were suggested. To increase oil recovery the machine was modified by reducing the cylinder to diameter of $9.5 \mathrm{~cm}$. Further suggestions on modification of the press include more diameter reduction for much higher oil expression pressure and shorter oil travel radial distance within the cake, replacing the hydraulic jack with the double acting hydraulic power cylinder to speed up piston retraction and cake removal. Current design and suggested modified design are shown in Figure 7.

\section{CONCLUSIONS AND RECOMMENDATIONS}

The hydraulic oil press machine described by Snyder and Casten (1985) was found to have low oil expression efficiency and improvement in oil recovery was achieved by reducing press cylinder diameter. The maximum oil recovery that was attained by pressing seeds in hydraulic oil press machine at $20.8 \mathrm{MPa}$ was $57.5 \%$ of seed oil. Various factors that are affecting oil recovery are seed moisture content, maximum pressure used, and cake thickness (amount of seeds pressed per batch).

For a hydraulic oil press machine to recover more than $50 \%$ of total oil from Jatropha seeds, design pressure should be more than $20 \mathrm{MPa}$ and cake thickness should be small. To speed up operation cycle, manual jack retraction should be improved by replaced motor vehicle jack with double action hydraulic power cylinder which can be retracted hydraulically.

\section{REFERENCES}

Bargale, P.C., Ford, R.J., Sosulski, F.W., Wulfsohn, D. and Irudayaraj, J. (1999). Mechanical Oil Expression from Extruded Soybean Samples, JAOCS, Vol. 76, No. 2,pp. 223-229.

Considine, D.M. and Considine, G.D. (1982). Food and Food Production Encyclopedia, van Nostrand Reinhold Company, New York.

De Jong J. (2010). The Jatropha Handbook: from Cultivation to Application, Eindhoven, The Netherlands.

Kabutey, A., Herák, D. and Sedláček, A. (2011).Behaviour of different moisture contents of Jatropha curcas L. seeds under compression loading. Res. Agr. Eng., Vol. 57, No. 2,72-77.

Kibazohi, O. (2006). Oil-mill press cake as a potential source of vegetable oil in Tanzania, Tanzania Engineer, Journal of the Institution of Engineers of Tanzania, Vol. 8, No. 2, pp. 53-60.

Otto, J. (1992). The ram press of Tanzania: Successful technology gets better. Food Chain, Vol. 5, pp. 6-7.

Snyder, H.E. and Casten, J. (1985).Volunteers in Technical Assistance, understanding pressure extraction of vegetable oils.

http://www.appropedia.org/Small_Scale Vegetable_Oil_Extraction_- (last accessed Aug. 2012). 